\title{
RANCANG BANGUN SISTEM INFORMASI GEOGRAFIS SARANA PENDIDIKAN DAN KESEHATAN BERBASIS WEB DI WILAYAH KABUPATEN GUNUNG MAS
}

\author{
Widiatry $^{1)}$, Devi Karolita ${ }^{2}$, Febriliana $^{3)}$ \\ ${ }^{1)}$ Jurusan Teknik Informatika Fakultas Teknik Universitas Palangka Raya \\ 2) Jurusan Teknik Informatika Fakultas Teknik Universitas Palangka Raya \\ ${ }^{3)}$ Jurusan Teknik Informatika Fakultas Teknik Universitas Palangka Raya \\ widiatry@gmail.com ${ }^{l)}$, devi_karolita@yahoo.com ${ }^{2}$,febriliana.ti@gmail.com
}

\begin{abstract}
ABSTRAK
Teknologi SIG (Sistem Informasi Geografis) merupakan suatu teknologi mengenai geografis yang telah sangat berkembang yang memiliki kemampuan dalam memvisualisasikan data spasial berikut dengan atribut-atributnya, seperti memodifikasi bentuk, warna, ukuran, dan simbol. Pengimplementasian teknologi SIG sangat diperlukan dalam pengelolaan dan pemanfaatan data informasi geografis seperti dalam hal pemetaan suatu lokasi sarana.

Dalam penulisan laporan ini akan membahas tentang bagaimana membangun sebuah Sistem Informasi Geografis (SIG) berbasis web untuk sarana pendidikan dan kesehatan di wilayah Kabupaten Gunung Mas pada kantor BAPPEDA. SIG ini dibuat dengan menggunakan metode UML-Based Web Engineering (UWE) yang terdiri dari empat langkah, yaitu Requirements Model (Use Case Model), Content Model (Conceptual Model), Navigation Model dan Presentation Model.

Dengan adanya SIG ini diharapkan dapat membantu memudahkan pihak kantor BAPPEDA dalam mengelola informasi geografis mengenai sarana pendidikan dan kesehatan yang ada di wilayah Kabupaten Gunung Mas.
\end{abstract}

Kata-kata kunci: BAPPEDA, Fusion Table, MySQL, PHP, Sarana Pendidikan, Sarana Kesehatan, Sistem Informasi Geografis

\section{ABSTRACT}

GIS technology (Geographic Information Systems) is a technology that has the geographical highly developed that has the ability to visualize spatial data. Implementing GIS technology is indispensable in the management and use of data in terms of geographic information as a means of mapping a location.

In writing this report will discuss about how to build a Geographic Information System (GIS) for web-based education and health facilities in the district of Gunung Mas on BAPPEDA office. GIS is made using the method of UML-Based Web Engineering (UWE) which consists of four steps, namely Requirements Model (Use Case Model), Content Model (Conceptual Model), Model Navigation and Presentation Model.

With the presence of GIS is expected to help facilitate the office BAPPEDA in managing geographic information regarding education and health facilities in the district of Gunung Mas.

Keywords: BAPPEDA, Fusion Table, MySQL, PHP, Education Facilities, Health Facilities, Geographic Information Systems

\section{PENDAHULUAN}

\section{Latar Belakang}

Perkembangan teknologi informasi saat ini sangatlah pesat. Hal ini mempengaruhi beberapa sektor pemerintahan seperti halnya dalam bidang pemetaan. Salah satu teknologi yang berperan penting saat ini ialah Sistem Informasi Geografis. Teknologi SIG (Sistem Informasi Geografis) / Geographic Information System (GIS) merupakan suatu teknologi mengenai informasi geografis yang telah sangat berkembang. Teknologi ini memiliki kemampuan dalam memvisualisasikan data spasial berikut dengan atribut-atributnya, seperti memodifikasi bentuk, warna, ukuran, dan simbol.

Oleh karena itu berbagai macam organisasi dan institusi menggunakan Sistem Informasi Geografis (SIG) untuk membangun, menyimpan, mengelola dan menampilkan informasi berefrensi geografis, misalnya data yang diidentifikasi menurut lokasinya dan disimpan dalam sebuah database.

Kabupaten Gunung Mas merupakan salah satu kabupaten di provinsi Kalimantan Tengah yang merupakan hasil pemekaran dari Kabupaten Kapuas provinsi Kalimantan Tengah berdasarkan 
UU Nomor 5 tahun 2002. Perkembangan Kabupaten Gunung Mas yang cukup pesat menuntut Badan Perencanaan dan Pembangunan Daerah (BAPPEDA) yang ada di Kabupaten Gunung Mas untuk meningkatkan kinerja dalam sektor pengelolaan dan pemanfaatan data informasi terkhusus pada bidang sosial dan budaya, yaitu untuk pengelolaan dan pemanfaatan data informasi geografis sarana pendidikan dan kesehatan yang ada di wilayah Kabupaten Gunung Mas.

Sampai saat ini pengelolaan dan pemanfaatan data informasi geografis pada kantor BAPPEDA untuk pemetaan sarana pendidikan dan kesehatan masih bersifat manual. Pegawai masih perlu memasukan data sarana secara manual pada peta, seperti untuk menambahkan titik koordinat dan jenis sarana masih perlu membuka peta dengan software arcgis yang masih bersifat Desktop based application dimana software hanya bisa digunakan jika sudah diinstal pada komputer. Selain itu, dalam penyimpanan data informasi tidak menggunakan DBMS (Database Management System) sehingga membuat data mudah hilang. Dalam pencarian data informasi pun masih bersifat manual yaitu harus dicari dalam lemari arsip sehingga menyita banyak waktu.

Berdasarkan pertimbangan tersebut maka dibutuhkan suatu aplikasi sistem informasi berbasis web yang mampu membantu kantor BAPPEDA dalam pengelolaan dan pemanfaatan data informasi geografis untuk sarana pendidikan dan kesehatan secara efisien dan efektif.

Oleh karena itu, di buatlah sebuah

"Rancang Bangun Sistem Informasi Geografis Sarana Pendidikan dan Kesehatan Berbasis Web di Wilayah Kabupaten Gunung Mas" pada kantor BAPPEDA.

\section{Tujuan dan Manfaat Penelitian}

Tujuan dari penulisan penelitian ini adalah sebagai berikut.

Membuat sebuah sistem informasi pengelolaan dan pemanfaatan data informasi terstruktur yang dapat membantu kantor BAPPEDA kabupaten Gunung Mas dalam mengelola dan memanfaatkan data informasi geografis sarana pendidikan dan kesehatan yang ada di wilayah kabupaten Gunung Mas.

Manfaat dari penulisan penelitian ini adalah sebagai berikut.

1. Membantu kantor BAPPEDA dalam mengelola dan memanfaatkan data informasi geografis sarana pendidikan dan kesehatan yang ada di wilayah kabupaten Gunung Mas yang masih dilakukan secara manual menjadi sistem pengelolaan data yang terstruktur dengan adanya aplikasi SIG berbasis web yang dibuat.

2. Membantu pihak Pemerintah Daerah Kabupaten Gunung Mas, khususnya kantor BAPPEDA Kabupaten Gunung Mas dalam menyediakan informasi geografis dalam bentuk peta untuk sarana pendidikan dan kesehatan bagi masyarakat.

\section{Metodologi Penelitian}

1. Alat dan Bahan

meliputi

Adapun alat dan bahan yang diperlukan

1. Perangkat keras (hardware) berupa laptop dengan spesifikasi Processor AMD Athlon X2 L310 - $1.2 \mathrm{GHz}$, 4GB DDR2, 320GB HDD, VGA ATi Radeon HD3200 dengan sistem operasi Windows 7 Ultimate 32-bit.

2. Perangkat lunak yang digunakan dalam pengembangan aplikasi ini adalah ArcView 3.3 untuk pembuatan peta berekstensi shp, Google Map API untuk pengambaran peta serta lokasi pada web, ESRI Converter untuk mengkonversi data spasial (ekstensi shp) ke kml, bahasa pemrograman PHP (Hypertext Prepocessor) versi 5.3 dan Dreamweaver CS 4 untuk pembuatan web serta $M y S Q L$ versi 5.5 untuk database dengan uji coba pada localhost WAMP Server versi 2.2.

\section{Metodologi Pelaksanaan}

Adapun metodologi pelaksanaan penelitian yang dilakukan meliputi:

\section{a. Identifikasi Awal}

Merupakan tahapan awal yang dilakukan, yaitu dengan mengidentifikasi persoalan yang menjadi alasan pembuatan Rancang Bangun Sistem Informasi Geografis Sarana Pendidikan dan Kesehatan Berbasis Web di Wilayah Kabupaten Gunung Mas, yang kemudian dilakukan perumusan masalah.

\section{b. Pengumpulan Data}

Merupakan tahap pengambilan data yang berhubungan dengan permasalahan yang sedang dibahas. Dalam pengumpulan data tersebut menggunakan teknik-teknik pengumpulan data, yaitu sebagai berikut.

1. Wawancara

Tahap ini merupakan pengumpulan data dengan melakukan wawancara dan meminta data yang diperlukan kepada Kantor Badan Perencanaan dan Pembangunan Daerah (BAPPEDA) kabupaten Gunung Mas untuk memperoleh informasi berkaitan masalah yang dihadapi.

2. Studi literatur 
Tahap ini merupakan pengumpulan data dengan cara mempelajari teori-teori literatur atau kajian pustaka dari buku-buku dan internet yang berhubungan dengan penelitian sebagai bahan atau dasar permasalahan.

\section{Pengolahan Data}

Metode yang digunakan dalam pengembangan sistem ini adalah metode $U M L$ Based Web Engineering (UWE). Langkahlangkah sebagai berikut dapat dilihat pada Gambar 1.1.

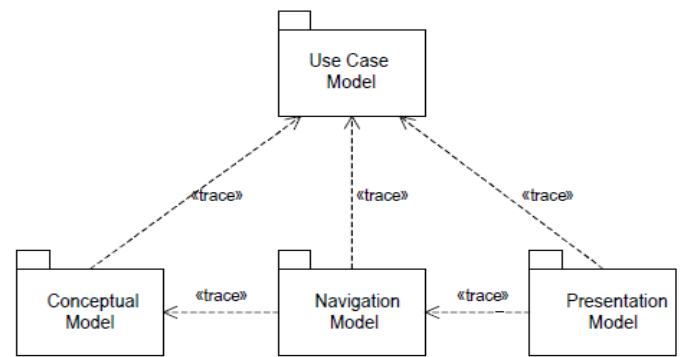

Gambar 1. Models Built during the Authoring Process of the UML-based Web Engineering Approach

(Sumber: Nora Koch, Alexander Knapp, Gefei Zhang, Hubert Baumeister, 2008, Web Engineering: Modelling and Implementing Web Applications, Part II, pp 157-191)

Proses pemodelan yang diusulkan oleh UWE terdiri oleh empat langkah berikut.

1. Requirements Model (Use Case Model)

Langkah awal untuk mengembangkan sistem web adalah identifikasi kebutuhan untuk aplikasi seperti yang ditentukan dalam UWE dengan requirements model. Tahap pertama, yaitu menentukan gambaran kasar dari fungsi yang dihasilkan yang dimodelkan dengan UML use case. Dan pada tahap kedua, menggambarkan tanggung jawab dan tindakan dari para sistem yang dimodelkan dengan UML activity diagram.

2. Content Model (Conceptual Model)

Proses membuat konten web berdasarkan kegiatan aktor (use case). Tahap pertama mengambarkan struktur web, hubungan kegiatan aktor dan database yang dimodelkan dengan UML Class diagram. Dan pada tahap kedua, mengambarkan interaksi dan sifat web yang dimodelkan dengan UML Sequence diagram.

3. Navigation Model

Proses mendesain alur navigasi di dalam web dan mempresentasikan nodes dan link di dalam struktur web untuk mencegah disorientasi didalam web. Struktur navigasi dijelaskan dengan menggunakan diagram navigasi, yang terdiri dari satu set node dan link. UWE membedakan antara berbagai jenis node, seperti kelas navigasi, menu, indeks dan query.

4. Presentation Model

Proses representasi struktur web kedalam sebuah desain user interface serta desain halaman web yang dimodelkan dengan Presentation Class.

\section{Requirements Model (Use Case Model)}

Dalam langkah pertama ini digunakan dua buah diagram, yaitu use case diagram yang digunakan untuk mengambarkan fungsi-fungsi di dalam web dan activity diagram yang digunakan untuk mengambarkan aliran kerja (Workflow) didalam web.

\section{a. Use Case Diagram}

Use case diagram merupakan permodelan untuk kelakukan (behavior) sistem informasi yang akan dibuat. Use case mendeskripsikan sebuah interaksi antara satu atau lebih aktor dengan sistem informasi yang akan dibuat. Use case digunakan untuk mengetahui apa saja yang ada di dalam sebuah sistem informasi dan siapa saja yang berhak menggunakan fungsifungsi itu.

a) Definisi Aktor

Aktor adalah orang, proses, atau sistem lain yang berinteraksi dengan sistem informasi yang dibuat. Pendefinisian aktor pada SIG Sarana Pendidikan dan Kesehatan berbasis web ini berdasarkan pada tahap analisis pengguna (user) yang diperlihatkan seperti pada tabel 1 berikut.

Tabel 1. Definisi aktor

\begin{tabular}{|cl|}
\hline No. Alktor & \multicolumn{1}{c|}{ Deskripsi } \\
\hline 1. Admin & Orang yang bertugas dan memiliki \\
& hak akses untuk melakukan operasi \\
& mengelola data sarana, titik koordinat, \\
& mencetak peta, mengelola akun, \\
& mengelola buku tamu, balas kiriman \\
& pesan buku tamu, ubah kontak kantor, \\
& ubah tentang kami (latar belakang \\
& kantor, visi dan misi dari kantor), \\
& melihat peta, cari sarana, filter sarana, \\
& dan lihat daftar sarana. \\
\hline & Orang yang hanya memiliki hak akses \\
& melihat peta, cari sarana, filter sarana, \\
& lihat daftar lokasi sarana dan mengisi \\
& buku tamu. \\
\hline 2. Pengunjung &
\end{tabular}


Berikut adalah diagram use case pada SIG Sarana Pendidikan dan Kesehatan berbasis web.

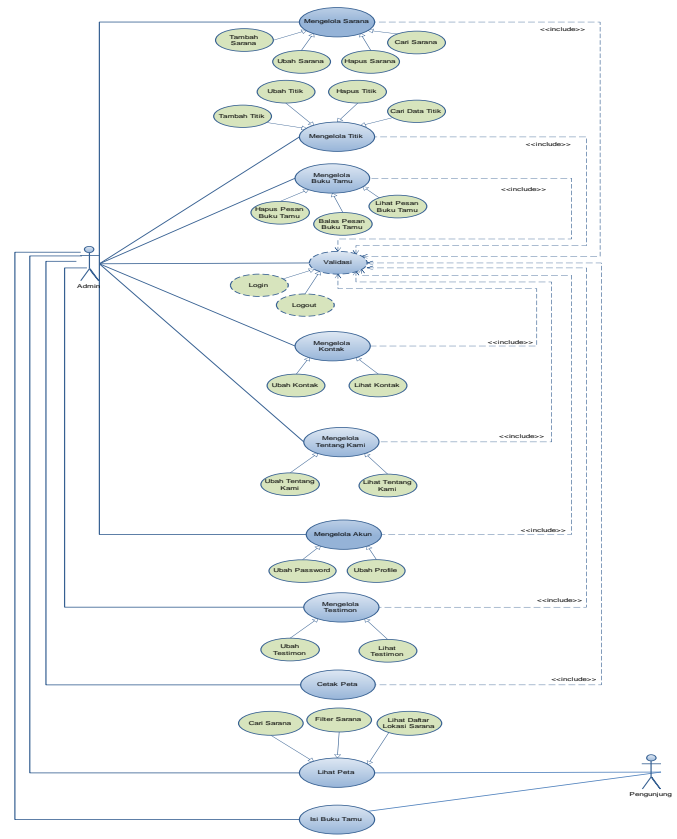

Gambar 1. Use case diagram SIG Sarana Pendidikan dan Kesehatan berbasis web
Activity diagram atau diagram aktivitas menggambarkan aliran kerja (workflow) atau aktivitas dari sebuah sistem atau proses bisnis atau menu pada perangkat lunak. Berikut adalah activity diagram pada SIG Sarana Pendidikan dan Kesehatan berbasis web.

\section{b. Activity Diagram}

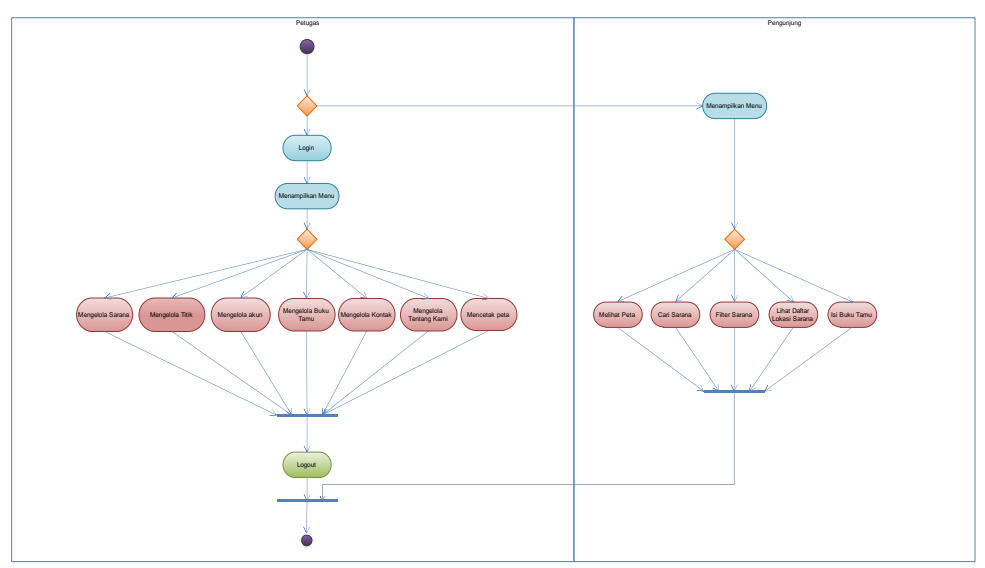

Gambar 2 Activity diagram SIG Sarana Pendidikan dan Kesehatan berbasis web

\section{Content Model (Conceptual Model)}

Langkah kedua pada metode UWE adalah membuat konten web berdasarkan kegiatan aktor (use case). Dalam langkah ini digunakan dua buah diagram, yaitu Class diagram yang digunakan untuk mengambarkan struktur web, hubungan kegiatan aktor dan database dan

Berikut adalah class diagram dari SIG Sarana Pendidikan dan Kesehatan berbasis web. sequence diagram untuk mengambarkan interaksi dan sifat web.

\section{a. Class Diagram}




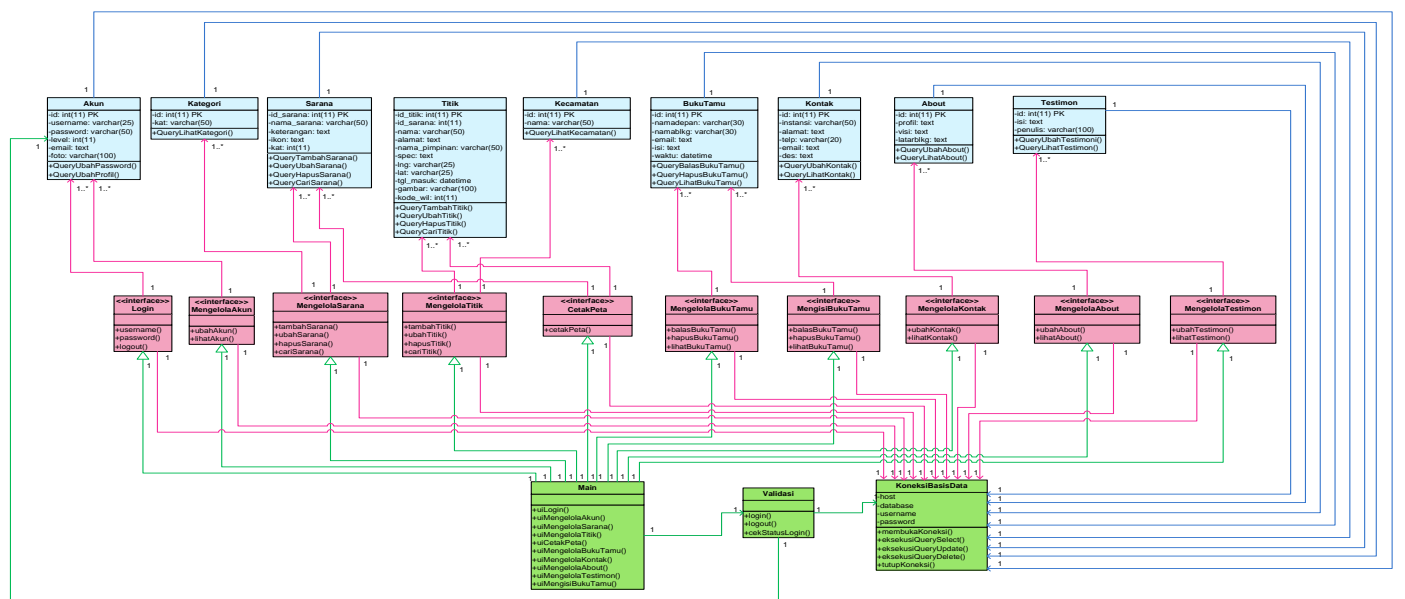

Gambar 3. Class diagram SIG Sarana Pendidikan dan Kesehatan berbasis web

\section{b. Sequence Diagram}

Berikut adalah diagram sekuen dari SIG Sarana Pendidikan dan Kesehatan berbasis web. Sequence Diagram: login

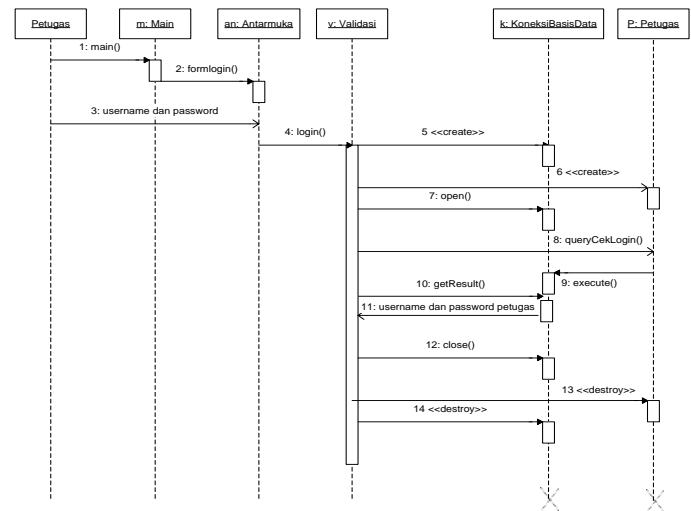

Gambar 4. Sequence diagram - login

Sequence Diagram: tambah sarana

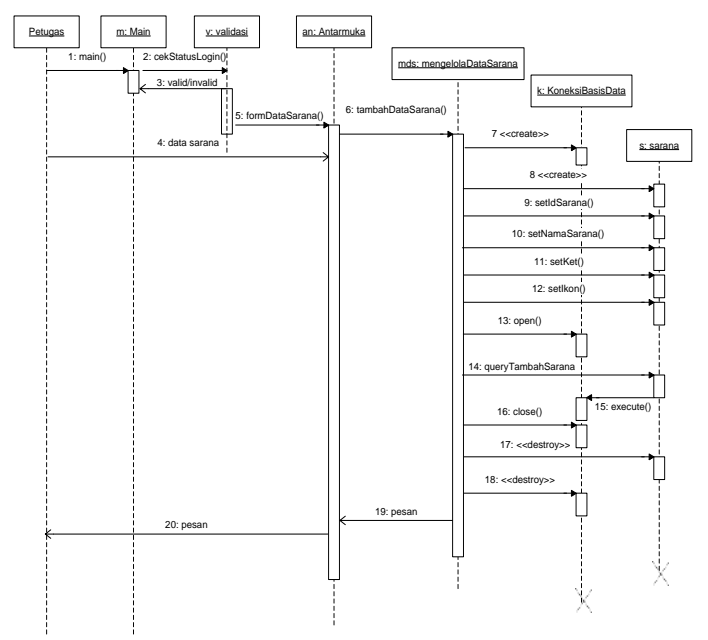

Gambar 5. Sequence diagram - tambah sarana
Sequence Diagram: ubah sarana

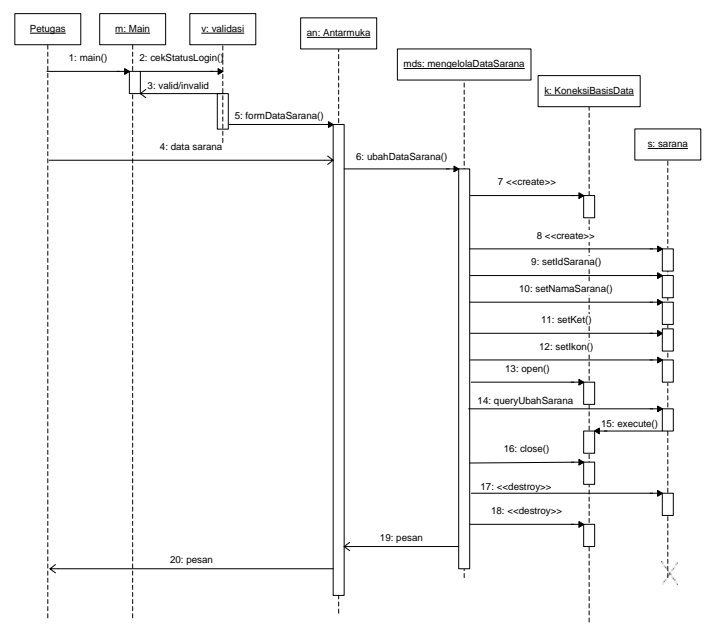

Gambar 6. Sequence diagram - ubah sarana

Sequence Diagram: hapus sarana

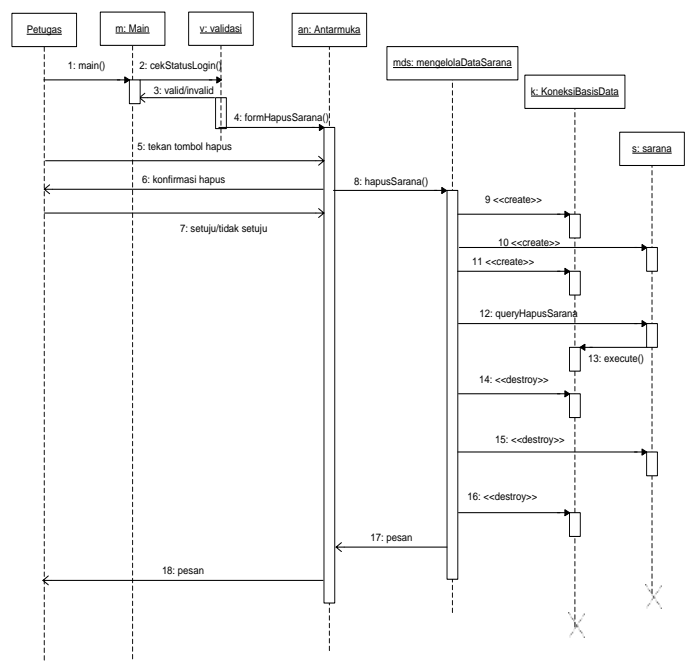

Gambar 7. Sequence diagram - hapus sarana 
Sequence Diagram: melihat peta

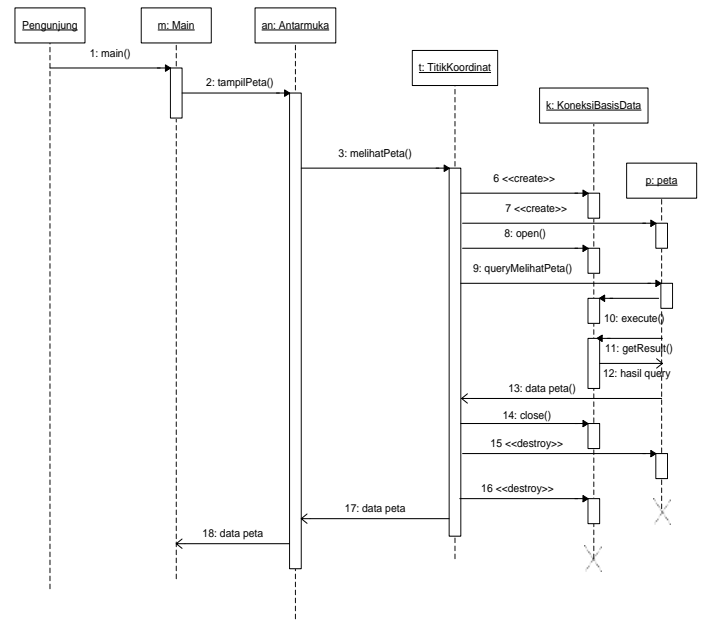

Gambar 8. Sequence diagram - melihat peta

\section{Navigation Model}

Proses mendesain alur Navigasi didalam web dan mempresentasikan Nodes dan Link didalam struktur web. Struktur navigasi dijelaskan dengan menggunakan navigation class dan navigation link
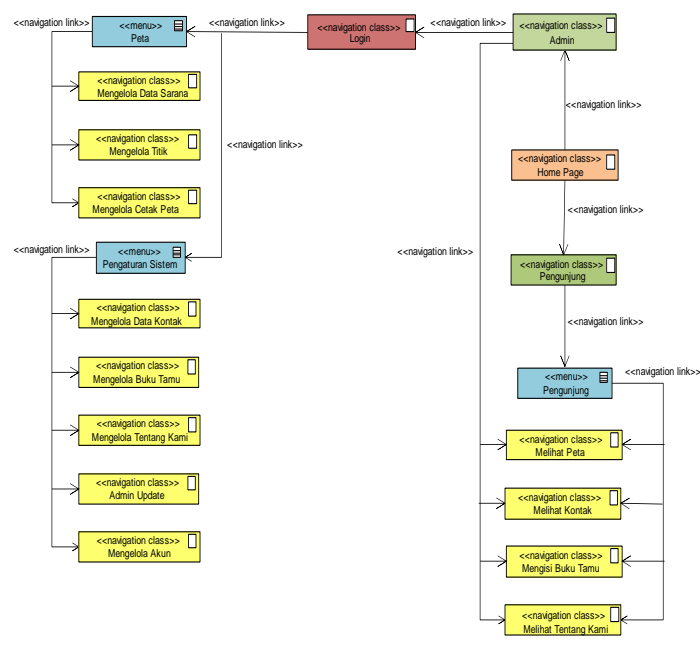

Gambar 9. Navigation model - SIG Sarana

Pendidikan dan Kesehatan berbasis web

\section{Presentation Model}

Proses representasi struktur web kedalam sebuah desain user interface serta desain halaman web. Alat yang digunakan adalah presentation class.

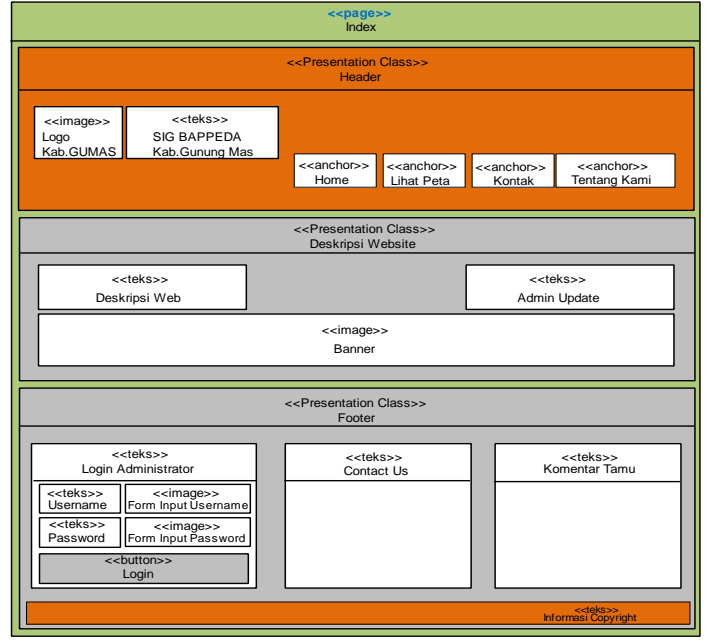

Gambar 10. Halaman awal

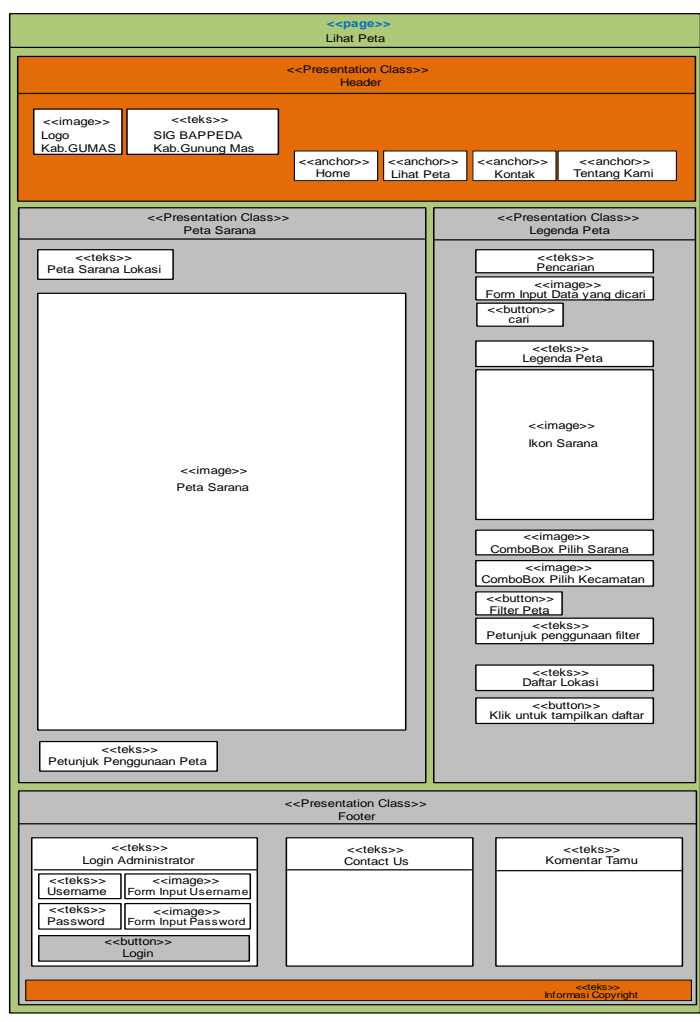

Gambar 11. Halaman lihat peta 


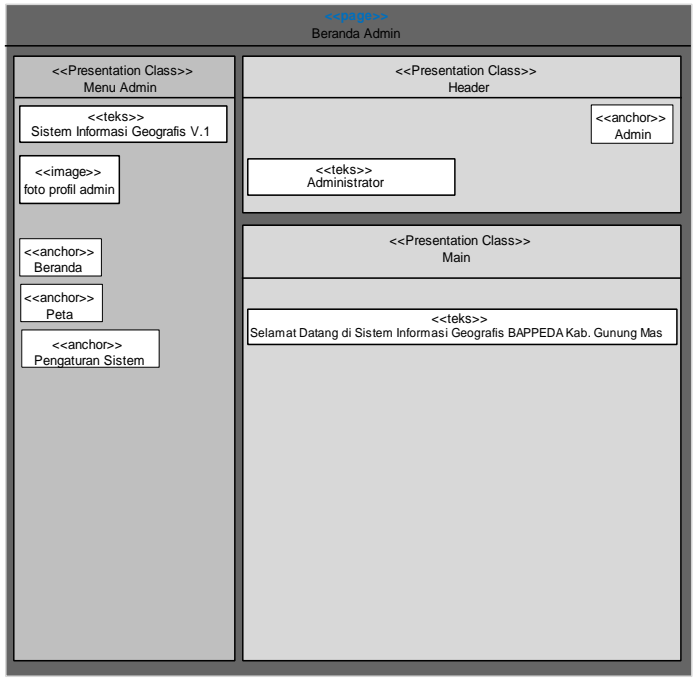

Gambar 12. Halaman awal admin

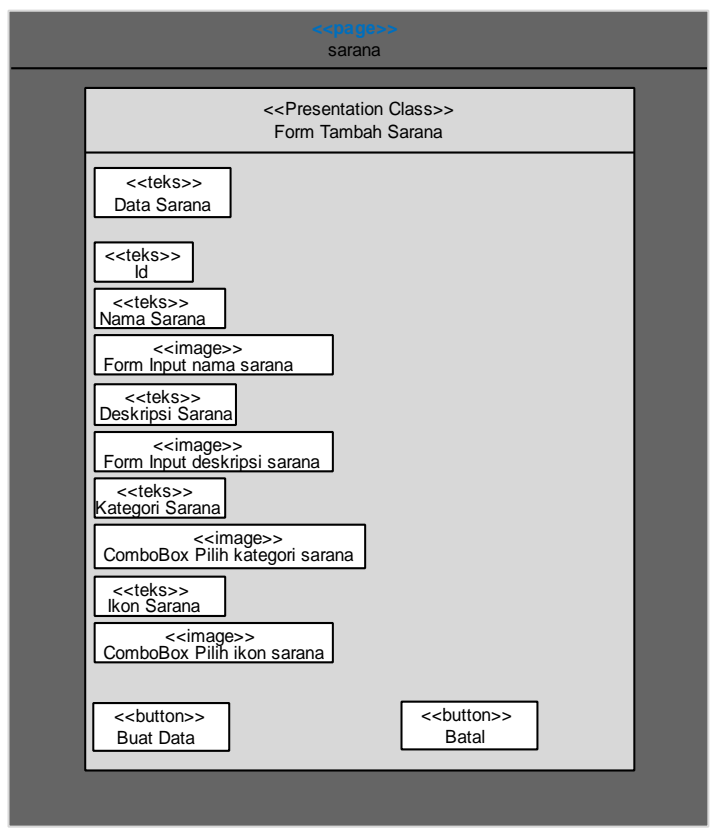

Gambar 13. Halaman tambah data sarana

\section{IMPLEMENTASI}

Tahap implementasi merupakan rangkaian pelaksanaan kegiatan yang dilakukan setelah tahap analisis dan desain sistem selesai dilaksanakan dengan tujuan yang ingin dicapai adalah dapat dioperasikannya hasil desain sistem yang dibuat.

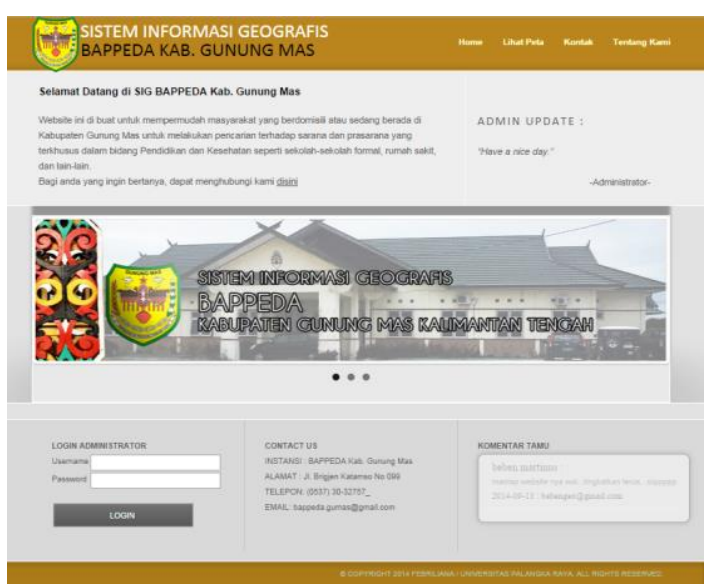

Gambar 14. Implementasi antarmuka halaman home

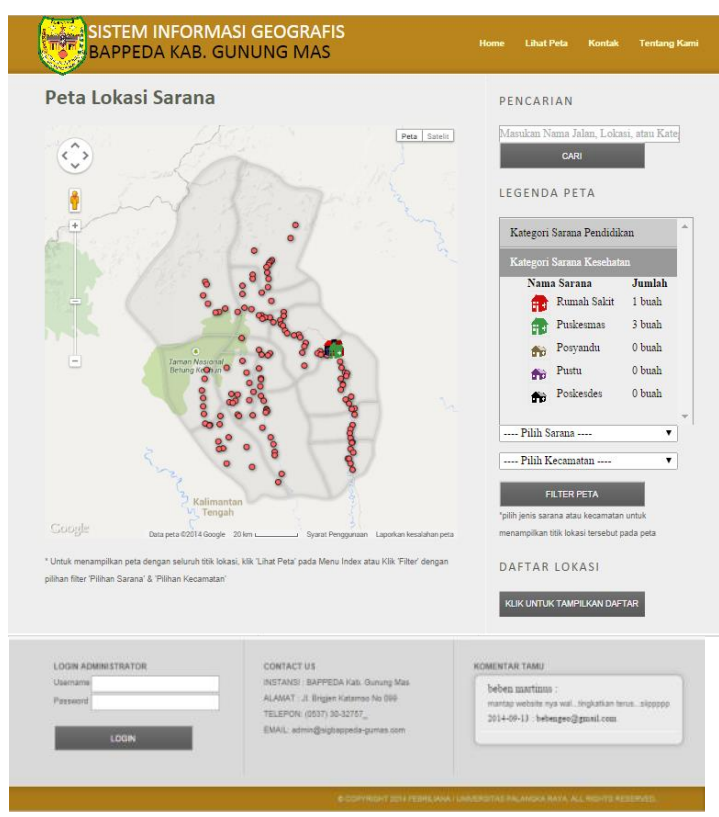

Gambar 15. Implementasi antarmuka halaman lihat peta

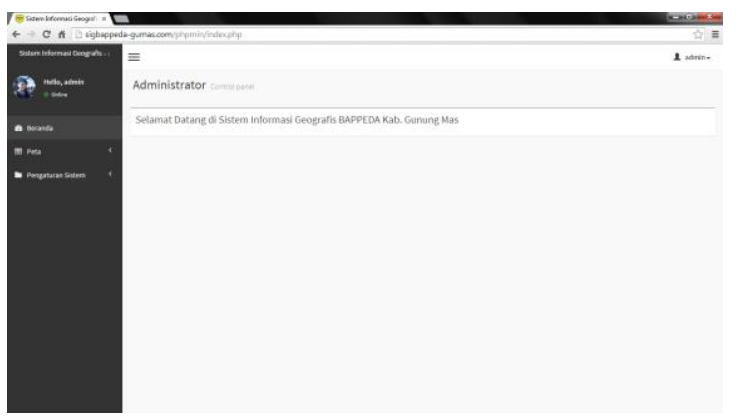

Gambar 16. Implementasi antarmuka halaman beranda admin 


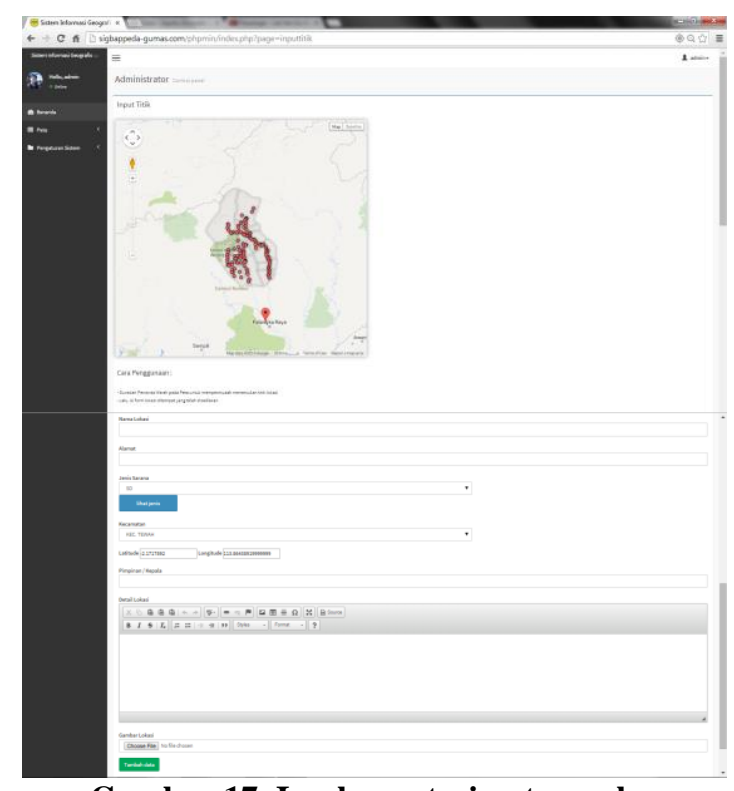

Gambar 17. Implementasi antarmuka halaman tambah titik

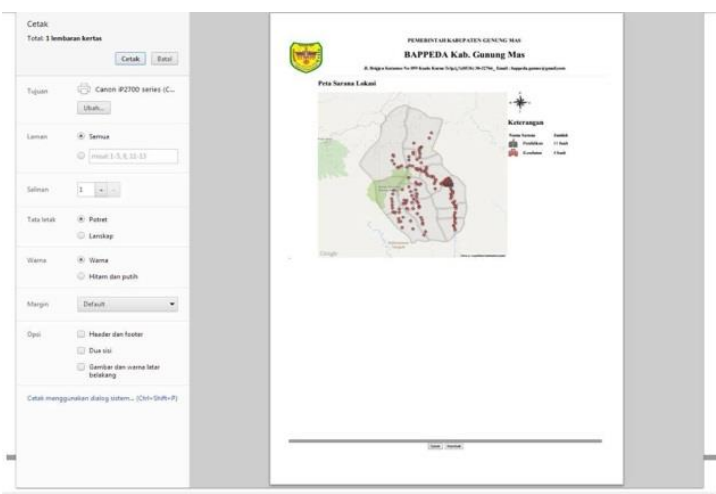

Gambar 18. Implementasi antarmuka halaman cetak peta

\section{KESIMPULAN}

Adapun kesimpulan yang dapat diambil adalah sebagai berikut.

Pembuatan Rancang Bangun Sistem Informasi Geografis Sarana Pendidikan dan Kesahatan Berbasis Web pada Kantor BAPPEDA Kabupaten Gunung Mas menggunakan metodologi penelitian seperti, metode identifikasi awal, pengumpulan data (melalui wawancara dan studi literatur), serta pengolahan data dengan metode UWE. Adapun tahapan-tahapan dalam metodologi UWE guna membangun sebuah perangkat lunak yaitu: Requirements Model (Use Case Model), Content Model (Conceptual Model), Navigation Model dan Presentation Model.

Proses Pembuatan peta menggunakan Fusion Table pada Google Map API dan pembuatan program menggunakan bahasa pemrograman PHP (Hypertext Prepocessor) versi 5.3 dengan MySQL versi 5.5 serta localhost WAMP Server versi 2.2. Peta ini juga dilengkapi dengan legenda, skala, fungsi zoom (in dan out) serta fasilitas pencarian, filter berdasarkan jenis sarana atau kecamatan dan keterangan jarak sarana dari ibu kota kabupaten.

Dengan adanya Sistem Informasi Geografis ini diharapkan dapat membantu memudahkan pihak kantor BAPPEDA dalam mengelola informasi geografis mengenai sarana pendidikan dan kesehatan yang ada di wilayah Kabupaten Gunung Mas.

\section{DAFTAR PUSTAKA}

Achmad Solihin. 2010. "Pengenalan DBMS dan MySQL”. Jakarta : Universitas Budi Luhur.

Aliyah, J.Fie. 2009. "Sistem Informasi Geografis Berbasis Web Mengenai Penyebaran Fasislitas Pendidkan, Perumahan, dan Rumah Sakit di Kota Bekasi”,http://www.gunadarma.ac.id/library/ articles/graduate/industrialtechnology/2009/Artikel_50404280.pdf. diakses pada tanggal 19 Oktober 2013 pukul 09.45 WIB

Aronoff, Stan. 1989. "Geographic Information System a Management Perspective". WDL Publication, Ottawa-Canada.

Bunafit Nugroho. 2004, "Aplikasi Pemrograman Web Dinamis dengan PHP dan MySQL", Gava Media, Yogyakarta.

Burrough, P.A. 1985. "Principles of Geographical Information Systems for Land Resources Assessmenl". Clarendon Press, Oxford.

Bafadal. Ibrahim. 2003 . "Peningkatan Profesional Guru SD”. Jakarta. Bumi Aksara.

Black, Rex. 2007. "Pragmatic Software Testing: Becoming an Effective and Efficient Test Professional". Hoboken : Wiley Publishing Inc.

Connolly, Thomas, Carolyn Begg. 2005. "Database Systems: A Practical Approach To Design, Implementation, and Management". (4th ed.) Addison Wesley, England

Ekadinata, Andree. 2008. "Sistem Informasi Geografis dan Penginderaan Jauh Menggunakan ILWIS Open". Bogor:ICRAF

Ekadinata, Andree. 2008. "Sistem Informasi Geografis Untuk Pengelolaan Bentang Lahan Berbasis Sumber Daya Alam". Bogor: World Agroforestry Centre(ICRAF)

Hakim, Lukmanul. 2013. "Proyek Website Super Wow! Dengan PHP dan jQuery”. Yogyakarta: Lokomedia

Hetzel, Bill. 2007. "The Complete Guide to Software Testing”. New York: John Wiley \& Sons.

Hidayat, A.Nur. 2010. "Rancang Bangun Dan Desain Sistem Informasi Geografis Profil Daerah Kota Blitar Berbasis Web”, http://lib.uinmalang.ac.id/files/thesis/fullchapter/05550114 
.pdf. diakses 22 oktober 2013 pada puku 20.51 WIB

Khafidli, M.Firgiawan. 2011. "Trik Menguasai HTML5, CSS3, PHP Aplikatif”. Yogyakarta: Lokomedia

Kang-Tsung Chang, 2002. "Introduction to Geographic Information System”, Mc.GrawHill.

Laudon, Kenneth C, Jane P. Laudon. 2004. "Management Information Systems: Managing the Digital Firm". (8th ed). Pearson Prentice Hall, New Jersey

McGregor, John, D. dan Sykes, David, A. 2001. "A Practical Guide to Testing Object Oriented Software”. New Jersey : Pearson Education

McLeod, R. \& Schell, G.P. 2007. "Management Information Systems", edisi ke-10. Pearson Prentice Hall, New Jersey

O'Brien, James A., Marakas, George M. 2006. "Management information systems". edisi ke7. McGraw-Hill

Peranginangin, Kasiman. 2006. “Aplikasi WEB dengan PHP dan MySQL, Yogyakarta: Andi.

Prahasta, Eddy. 2001. "Konsep-Konsep Dasar Sistem Informasi Geografts". CV. Informatika, Bandung

Prahasta, Eddy. 2005, "Sistem Informasi Geografis : Aplikasi Pemograman MapInfo". CV. Informatika, Bandung.

Prahasta, Eddy. 2007. "Sistem Informasi Geografis: Tutorial ArcView”. Bandung: Informatika

Prahasta, Eddy. 2009. "Sistem Informasi Geografis: Konsep-Konsep Dasar (Perspektif Geodasi \& Geomatika)”. Bandung: Informatika

Tian, J. 2005. "Software Quality Engineering: Testing, Quality Assurance, and. Quantifiable Improvement" . Hoboken: John Willey \& Sons, Inc.

Tianur, I.Lidya. 2011. "Sistem Informasi Geografis Kost Di Sekitar Universitas Palangkaraya Berbasis Web”. Jurusan Teknik Informatika Fakultas Teknik Universitas Palangkaraya

Turban,Rainer, Potter. 2003. "Introduction To Information Technology". Second Edition. John Wiley \& Sons, Inc, New Jersey.

Wahyuningrum. 2004. "Buku Ajaran Manajemen Fasilitas Pendidikan”. (Online) staff.uny.ac.id/sites/default/files/BAB\%20Ma naj\%20Fasilitas.pdf, diakses pada tanggal 19 Oktober 2013 pukul 20.04. 